\title{
Differential responses of Bolivian timber species to prescribed fire and other gap treatments
}

\author{
DEBORAH K. KENNARD ${ }^{1, *}$ and FRANCIS E. PUTZ ${ }^{2}$ \\ 'U.S.D.A. Forest Service, Auburn, Alabama 36849, USA; ${ }^{2}$ Department of Botany, University of \\ Florida, Gainesville, Florida 32611,USA; *Author for correspondence (e-mail: dkennard@fs.fed.us)
}

Received 16 September 2002; accepted in revised form 9 June 2004

Key words: Disturbance intensity, Prescribed burning, Regeneration strategies, Seedling growth, Shade-tolerance, Sprouting

\begin{abstract}
We followed the establishment and growth response of 13 commercial tree species to canopy opening, above-ground biomass removal, and experimental burns of low and high intensities in a lowland dry forest in Bolivia. Three patterns of response to treatments were observed among the most abundant commercial tree species. (1) Shade-intolerant species regenerated mostly from seed and had the highest survival and growth rates following high-intensity burns. (2) Shadetolerant species were abundant in gap control and plant removal treatments. Treatments had little effect on the height growth of these species. (3) Individuals of root sprouting species were most abundant following plant removal and low-intensity burn treatments. Treatments had little effect on the height growth of these species. The wide variation in species' responses to gap treatments found in this study not only reinforces the concept that species are distributed along a continuum of shade-tolerance levels, but that other aspects of species' biology, such as seed dispersal type or sprouting behavior, further differentiate regeneration strategies. The variety of regeneration strategies found among the species at this forest site will require a flexible management scheme that mixes more intensive silvicultural treatments such as prescribed burning with less intensive treatments.
\end{abstract}

\section{Introduction}

The Chiquitania region in eastern Bolivia contains one of the largest and most diverse tropical dry forests in the neotropics (Gentry 1993; Killeen et al. 1998). Due to recent expansion in industrial agriculture and settlement, this area is also considered one of the most endangered ecosystems in South America (Dinerstein et al. 1995). Consequently, there has been a growing interest on the part of the Bolivian government to discourage the conversion of forests to competing, non-forest land uses by fostering natural forest management practices (Nittler and Nash 1999). Yet, in most managed dry forests in this region, sustainable management is threatened by a distinct lack of regeneration among valuable timber species (Mostacedo and Fredericksen 1999).

Management techniques for improving tree regeneration should be based on natural regeneration requirements of target species. Often, these techniques are chosen based on the shade-tolerance of timber species. For example, management of many shade-tolerant or 'climax' species entail protecting advance 
regeneration during harvesting and enhancing its growth to mature stages. Techniques for promoting the regeneration of shade-intolerant or 'pioneer' species usually involve creating sites suitable for seed germination and seedling establishment and promoting safe arrival of seeds to these sites (Dickinson 1998).

Although this pioneer-climax dichotomy often provides a useful paradigm for forest managers, regeneration strategies of many tropical tree species fall between the two extremes of completely shade-intolerant or shade-tolerant (Augspurger 1984; Condit et al. 1996). In fact, most tropical forest tree species are both shade-tolerant and gap-dependent, meaning they have the ability to persist in a seedling bank in forest understories but require canopy opening to reach maturity (Hartshorn 1989). The interaction of this continuum of tree regeneration strategies and the array of silvicultural treatments of varying intensities is inherently complex. Before management techniques can be prescribed on a large scale, the effects of silvicultural techniques on all tree species in question should be examined. For example, what are the effects of more intense silvicultural techniques on the advance regeneration of more shadetolerant trees? Or, what is the minimum disturbance level required for the regeneration of more shade-intolerant trees?

We examined the effects of treatments of varying disturbance intensities on the regeneration of commercial tree species in a Bolivian dry forest. We followed the responses of 13 commercial tree species to experimental canopy opening, above-ground biomass removal, and controlled burns of low and high intensities. Using a subset of these species, we also addressed whether their regeneration was limited by seed dispersal or by suitable establishment sites. This experiment is part of a larger study examining the effects of fire intensity on dry forest soils and plant community structure and diversity (Kennard and Gholz 2001; Kennard et al. 2002). Evidence has suggested that fire, of both natural and anthropogenic origins, has been a pervasive influence on Bolivian dry forests, and Bolivian forest managers have begun to explore prescribed burning as a silvicultural tool (Stanley 1995). An additional goal of our study was to determine if prescribed burning would be a viable management technique in these dry forests.

\section{Methods}

\section{Study region and sites}

This study was conducted in the Lomerio Community-owned Forest, Province of Nuflo de Chavez, Department of Santa Cruz, Bolivia ( $\left.16^{\circ} 45^{\prime} \mathrm{S}, 61^{\circ} 45^{\prime} \mathrm{W}\right)$. Lomerio is situated in the heart of Chiquitania, which lies in the transition zone between the humid forests on the southern rim of the Amazon basin and the thorn scrub formations of the Gran Chaco. The natural vegetation is classified as tropical dry forest (sensu Holdridge 1967). The regional climate is characterized by a strong dry season from May to October. The mean annual temperature at Concepcion, a town approximately $50 \mathrm{~km}$ from the study site, 
is $24.3{ }^{\circ} \mathrm{C}$ with temperatures that vary between $3{ }^{\circ} \mathrm{C}$ (July) and $38.1{ }^{\circ} \mathrm{C}$ (October) (Killeen et al. 1990). Mean annual precipitation is $1129 \mathrm{~mm}$. The landscape is dominated by low hills composed of granite, gneiss, and metamorphic rocks of Precambrian origin (Geobold 1981) punctuated by exposed granitic outcrops (inselbergs). The soils of the area are classified as Inceptisols and Oxisols (Ippore 1996). Elevation varies between 400 and $600 \mathrm{~m}$ a.s.l. Canopies of mature forest range from 12 to $20 \mathrm{~m}$ tall and are dominated by trees of the family Leguminosae $(60 \%$ of total basal area of trees $>10 \mathrm{~cm}$ $\mathrm{dbh}$ ); trees in the families Bignoniaceae, Anacardiaceae, and Bombacaceae are also abundant (Killeen et al. 1998). Understory trees are mostly represented by the families Sapindaceae and Myrtaceae. A spiny ground bromeliad, Pseudananas sagenarius, is distributed over approximately $80 \%$ of the forest floor (MacDonald et al. 1998).

\section{Experimental design and treatments}

Study plots were located in a management unit that was selectively harvested in 1997 (harvesting intensity of $4.4 \mathrm{~m}^{3} \mathrm{ha}^{-1}$ ). In June of the same year, 16 recently formed felling gaps were located and each gap divided into four $10 \times 10 \mathrm{~m}$ plots by cardinal axes originating from the gap center. Existing gap area was enlarged to a uniform $20 \times 20 \mathrm{~m}$ area by cutting all vegetation $>2 \mathrm{~m}$ tall (sensu Brokaw 1985) by machete or chainsaw. One of four treatments was randomly assigned to each $10 \times 10 \mathrm{~m}$ plot within each gap: (1) high-intensity burn; (2) low-intensity burn; (3) above-ground plant and coarse debris removal (hereafter referred to as plant removal); and (4) a gap control. A forest plot was located $\sim 20-25 \mathrm{~m}$ from each gap in unlogged forest.

Other than cutting all vegetation $>2 \mathrm{~m}$ tall, vegetation and woody debris in the gap control were not manipulated. In the plant removal and low-intensity burn treatments, all vegetation was cut at or near the soil surface and everything $\geq 2.5 \mathrm{~cm}$ diameter was removed and distributed as evenly as possible in the high-intensity burn treatment. Therefore, after fuels were manipulated and before prescribed burns, the plant removal and low-intensity burn treatments had similar amounts of litter and woody debris and no above-ground vegetation. Pre-burn fuel loads in high-intensity burn treatment subplots ranged from 10.8 to $82.8 \mathrm{~kg} / \mathrm{m}^{2}$ and averaged $48 \pm 4.9 \mathrm{~kg} / \mathrm{m}^{2}$ (mean $\pm 1 \mathrm{SE}$ ). Almost half of this mass was comprised of fuels $>7.5 \mathrm{~cm}$ diameter. Fuel loads in the low-intensity burn treatment subplots ranged from 0.8 to $4 \mathrm{~kg} / \mathrm{m}^{2}$ and averaged $2.2 \pm 2.3 \mathrm{~kg} / \mathrm{m}^{2}$. Sixty-six percent of the fuel mass in low-intensity plots was fine fuel, $<6 \mathrm{~mm}$ diameter.

Slash was left for five rainless weeks to dry and prescribed burns were conducted from August 29 to September 1, 1997, near the end of the 5-month dry season. A circular ignition technique was used for both burn treatments. Maximum soil temperature during burns was measured at 0 and $3 \mathrm{~cm}$ depths using temperature indicating paints (Tempilaq®, Tempil Corporation). 
Three weeks following burns, four permanent subplots $(2 \times 2 \mathrm{~m}$ each $)$ were established in each treatment plot, two located near the gap center and two located near the gap edge. Two additional subplots were established at random points in undisturbed forest $15-20 \mathrm{~m}$ from the edge of each gap.

Treatment effects on microhabitat, colonizing plant cover, and canopy cover

Litter depth $(\mathrm{cm})$ and percent cover by debris $2-20$ and $>20 \mathrm{~cm}$ diameter were estimated visually for each of the permanent $4 \mathrm{~m}^{2}$ subplots 1.5 months following burns. Soil temperature to $3 \mathrm{~cm}$ depth was measured in each treatment 3 months following burns. Percent plant cover was visually estimated in each subplot $1.5,3,6,9,12$, and 18 months after burns. In forest plots, only cover $<2 \mathrm{~m}$ tall was estimated. Percent canopy cover was measured with a spherical densiometer above each gap center, gap edge, and forest plot 3 months following burns.

\section{Seed addition treatment}

A seed addition treatment was used to determine if seed availability limited seedling densities. Seeds of four commercial timber species (Table 1) were placed in one randomly selected subplot $\left(4 \mathrm{~m}^{2}\right)$ of each pair at the following seeding densities: 5 seeds $/ \mathrm{m}^{2}$ of A. colubrina, A. urundueva, and C. chodatiana; and, $2.5 \mathrm{seeds} / \mathrm{m}^{2}$ (10 per plot) of $C$. microchaete. Seeds were placed on the litter or soil surface, depending on the soil surface conditions in each treatment.

Viability of seeds collected for the seed addition treatment was determined in germination trials conducted over a 60 day period (November-January, 1997). One-hundred seeds of each of the five species were planted in five trays (20 seeds per tray) of a 50:50 mix of sand and soil. Trays were placed in a location receiving morning shade and afternoon sun and were watered each morning. Newly germinated seeds were counted and removed daily.

\section{Seedling and sprout density, height, and RGR measurements}

Seedlings have been variously defined as individuals still dependent on seed reserves (e.g., Garwood 1983), to individuals up to $2.7 \mathrm{~m}$ tall (Whitmore 1989). In this study, we did not use size or physiology as a defining character, rather we defined seedlings as individuals originating from seed as opposed to those regenerating as sprouts. Seedling and/or sprout density and height were measured in each $4 \mathrm{~m}^{2}$ subplot (both seeded and unseeded treatments) at 1.5, 3, 6, 9,12 , and 18 months after burns. At each sampling period, all commercial species within subplots (of both seeded and unseeded species) were identified as sprouts or seedlings, tagged, and height to the apical meristem measured. 
Table 1. Characteristics of commercial tree species used in seed addition treatment or those species with sufficient regeneration for statistical analysis. Ecological classification of shade tolerance of regeneration taken from Pinard et al. 1999

\begin{tabular}{|c|c|c|c|c|c|c|}
\hline Species name & Family & $\begin{array}{l}\text { Seed } \\
\text { addition } \\
\text { treatment }\end{array}$ & $\begin{array}{l}\text { Shade } \\
\text { tol. }\end{array}$ & Dispersal & $\begin{array}{l}\text { Dispersal } \\
\text { unit }\end{array}$ & Fruit characteristics \\
\hline $\begin{array}{l}\text { Anadenanthera colubrina } \\
\text { (Vell. Conc.) }\end{array}$ & Mimosoideae & y & 1 & Gravity & Seed & Legume, $10-25 \mathrm{~cm}$ long \\
\hline $\begin{array}{l}\text { Aspidosperma rigidum } \\
\text { Rusby }\end{array}$ & Apocynaceae & $n$ & 3 & Wind & Seed & Pod, $6 \times 5 \mathrm{~cm}$ \\
\hline $\begin{array}{l}\text { Astronium urundeuva } \\
\text { (Allemao) Engl. }\end{array}$ & Anacardiaceae & $\mathrm{y}$ & 1 & Wind & Fruit & Small dried drupe, calyx to $1 \mathrm{~cm}$ \\
\hline $\begin{array}{l}\text { Caesalpinia floribunda } \\
\text { Tul. }\end{array}$ & Caesalpinaceae & $\mathrm{n}$ & 2 & Gravity & Seed & Legume, $10-15 \mathrm{~cm}$ long \\
\hline $\begin{array}{l}\text { Centrolobium microcheate } \\
\text { (C. Marius ex Benth) }\end{array}$ & Papilinoideae & $\mathrm{y}$ & 1 & Wind & Fruit & Samara, $8-10 \mathrm{~cm}$ long $\times 3-4 \mathrm{~cm}$ wide \\
\hline $\begin{array}{l}\text { Copaifera chodatiana } \\
\text { Hassler }\end{array}$ & Caesalpinaceae & $\mathrm{y}$ & 3 & Animal & Seed & Dry pod, $2 \times 3 \mathrm{~cm}$ seeds with oily aril \\
\hline
\end{tabular}

Shade-tolerance: 1 , shade-intolerant; 2 , partially shade-tolerant; 3 , shade-tolerant. 
Relative height growth rates (hereafter referred to as RGR) was calculated as:

$$
\text { RGR }=\left[\ln \left(\text { height }_{t_{2}}\right)-\ln \left(\text { height }_{t_{1}}\right)\right] /\left(t_{2}-t_{1}\right),
$$

where $t_{1}$ and $t_{2}$ are two measurement periods. Seedlings of Anadenanthera were extremely abundant in 1997 , therefore a maximum of three randomly selected individuals per subplot were tagged for height measurements and the remaining individuals counted. In addition to the four species used in the seed addition treatment, seven other commercial tree species were found in treatment plots and tagged for density and height measurements, however only two of these species (Aspidosperma rigidum Rusby and Caesalpinia floribunda Tul.) were found in sufficient numbers for statistical analyses.

\section{Statistics analyses}

Litter depth, soil temperature, debris cover, percent plant cover, and canopy cover were compared among treatments using ANOVAs with treatments as fixed effects and blocks as random effects followed by Tukey's HSD post hoc comparisons. All percentages (debris cover, plant cover, canopy cover) were transformed using the arcsine transformation before analyses.

Seedling densities of most tree species could not be normalized, therefore seedling densities were analyzed using Kruskall-Wallis non-parametric tests (SPSS 1998). Separate tests were run for each species by month, testing for the effects of the seeding treatment and gap treatments on densities. For species that regenerated from both seeds and sprouts, these regeneration modes were analyzed separately to compare densities among treatments. Overall densities of seedlings and sprouts were also compared for each month. Square-root transformed densities of Anadenanthera were normally distributed, therefore densities of these species were compared using repeated measures ANOVAs, using the seeding treatment and gap treatments as factors.

Seedling height and RGR were analyzed separately for each species using repeated measures ANOVAs with gap treatments and, for the species that sprouted, regeneration mode as factors. The effects of location within gap on seedling height and RGR was tested for Anadenanthera; other species were not sufficiently abundant for this test. For species with prolonged seedling establishment or sprouting, RGRs were calculated using the 6 month measurement as the initial height.

\section{Results}

Maximum temperature of controlled burns

Temperatures at the soil surface during high-intensity fires averaged $704 \pm 42{ }^{\circ} \mathrm{C}(x \pm \mathrm{SE}, n=16)$. The highest temperature measured was 
$927^{\circ} \mathrm{C}$. Temperature at $3 \mathrm{~cm}$ depth averaged $227 \pm 27^{\circ} \mathrm{C}(n=16)$. Flame heights ranged from 1.5 to $5 \mathrm{~m}$.

Temperatures at the soil surface during low-intensity fires averaged $225 \pm 33{ }^{\circ} \mathrm{C}(n=12)$; the highest temperature measured was $413^{\circ} \mathrm{C}$. Elevated temperatures at $3 \mathrm{~cm}$ were only detected in 2 of 16 plots; these averaged $107 \pm 7{ }^{\circ} \mathrm{C}(n=2)$. Flame heights were low, ranging from 10 to $50 \mathrm{~cm}$.

Treatment effects on microhabitat, colonizing plant cover, and canopy cover

Gap treatments significantly altered litter depth, debris cover, and soil temperature from conditions characteristic of forest understories 6 weeks after controlled burns (Figure 1). Total plant cover increased greatly in all gap treatments over the 18-month post-burn sampling period and significantly differed among treatments during the first 12 months (Figure 2). By 18 months, total plant cover in the gap control, plant removal, and lowintensity burn treatment had converged, and cover in the high intensity burn treatment was similar to that of forest understories. Canopy cover above forest plots $(78 \%)$ was significantly higher than canopy cover above gap treatments (mean $=22 \% ; p<0.001)$.

\section{Effects of seed addition treatment on seedling densities}

Seed addition increased seedling densities of Centrolobium $(p<0.001)$ and Copaifera $(p<0.001)$ but not those of Anadenanthera or Astronium. In greenhouse germination trials, percent germination of these four species were: $88 \%$ (Copaifera), 79\% (Anadenanthera), 50\% (Astronium), and 4\% (Centrolobium).

Gap treatment effects on density, survival, height, RGR of selected species

Anadenanthera. Due to an unusually large seed crop that was dispersed soon after burn treatments in 1997, Anadenanthera seedling density was the highest among all commercial species by an order of magnitude and, for this reason, this species is displayed in more detail (Figure 3). Three months after burns, Anadenanthera seedling density was highest in forest understory plots $(F=6.1, p<0.001$ ) (Figure 3a). Density declined in forest understories due to high mortality (Figure $3 \mathrm{~b}$ ) and by 12 months, densities in forest understories were similar to those in the plant removal, high intensity, and low intensity burn treatments. Anadenanthera seedling density was lowest in gap control plots by the end of the 18-month observation period $(F=3.8, p=0.02)$.

Anadenanthera seedlings in high and low-intensity burn treatments were significantly taller than seedlings in the gap control or forest understory; 

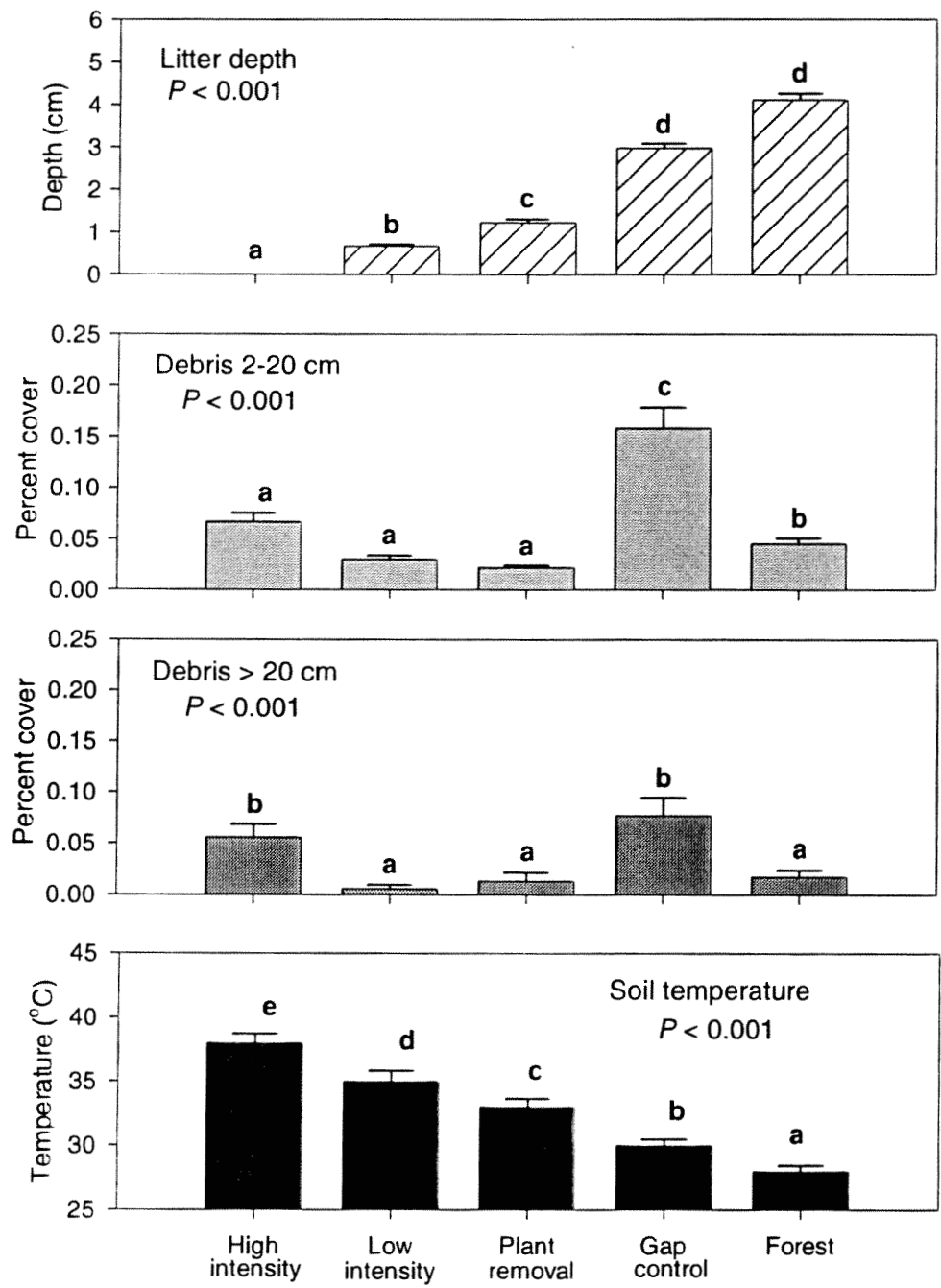

Figure 1. (a) Litter depth, (b) percent cover of debris $2-20 \mathrm{~cm}$, (c) percent cover of debris $>20 \mathrm{~cm}$ diameter, and (d) mid-day soil temperature in four treatments and forest controls 6 weeks after experimental burns. Treatments with the same letter are not significantly different. Bars represent standard errors $(n=16)$.

seedling height in the plant removal treatment was intermediate $(F=15.4$, $p<0.001$ ) (Figure 3c). Correspondingly, differences in RGRs among treatments were significant and patterns followed those for height $(F=18.4$, 


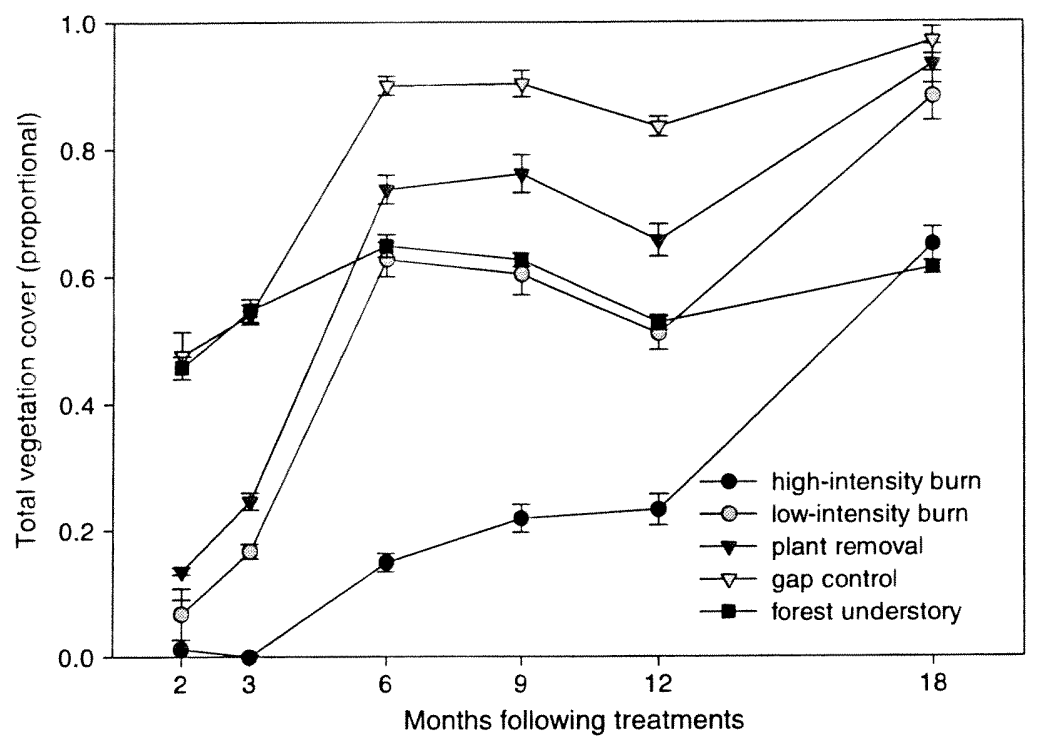

Figure 2. Total plant cover (visually estimated in $4 \mathrm{~m}^{2}$ subplots) among 4 treatments and forest controls at $2,3,6,9,12$, and 18 months following experimental burns. There was a significant treatment $x$ time interaction when tested with a repeated measures model, therefore total plant cover was tested separately by month ( 3 months: $F=98.7, p<0.0001 ; 6$ months: $F=70.6$, $p<0.0001$; 9 months: $F=77.4, p<0.0001 ; 12$ months: $F=58.7, p<0.0001$; 18 months: $F=36.7, p<0.0001)$. Bars represent standard errors $(n=16)$.

$p<0.001$ ) (Figure 3d). Anadenanthera seedlings also were taller and had higher RGRs in gap centers than near gap edges $(F=21.8, p<0.001$; $F=16.0, p<0.001$ ).

Astronium. The highest Astronium seedling densities were found in the highintensity burn, low-intensity burn and plant removal treatments (Figure 4). Only two Astronium individuals were found in all 16 gap control plots (but these died during the 18 month sampling period) and no Astronium seedlings were found in forest plots.

Although heights and RGRs of Astronium seedlings were not significantly different among treatments $(F=4.0, p=0.11 ; F=1.0, p=0.40$, respectively), there was a distinct trend of taller Astronium seedlings with increasing treatment intensity. Mean height of Astronium seedlings in high-intensity burn treatments was $150 \mathrm{~cm}$, more than twice the height of seedlings in plant removal treatments $(65 \mathrm{~cm})$. Also, the tallest Astronium seedling $(4 \mathrm{~m}$ at $18 \mathrm{mo})$ was found in a high-intensity burn plot.

Centrolobium. Centrolobium regenerated both from seeds and root sprouts (Figure 4). Density of root sprouts was higher than seedling density at 

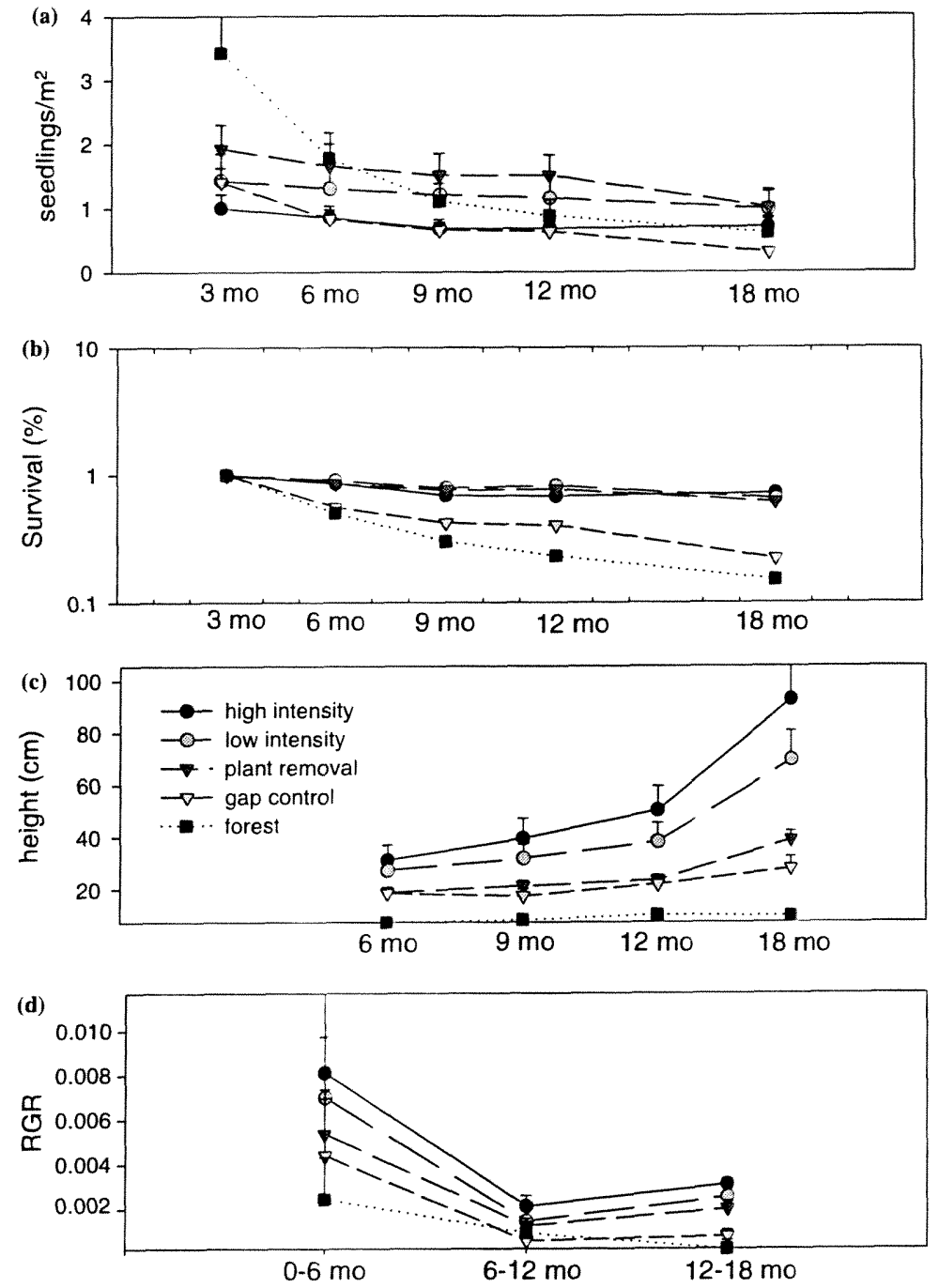

Figure 3. (a) Seedling density, (b) percent seedling survival, (c) seedling height, and (d) seedling relative height growth rates for Anadenanthera colubrina in the four treatments and forest controls. All graphs follow the legend shown in graph C. Bars represent standard errors $(n=16)$.

6 months $\left(X^{2}=5.9, p=0.02\right)$. All of the seedlings were located in seed addition subplots; apparently natural regeneration of this species was composed entirely of root sprouts. 

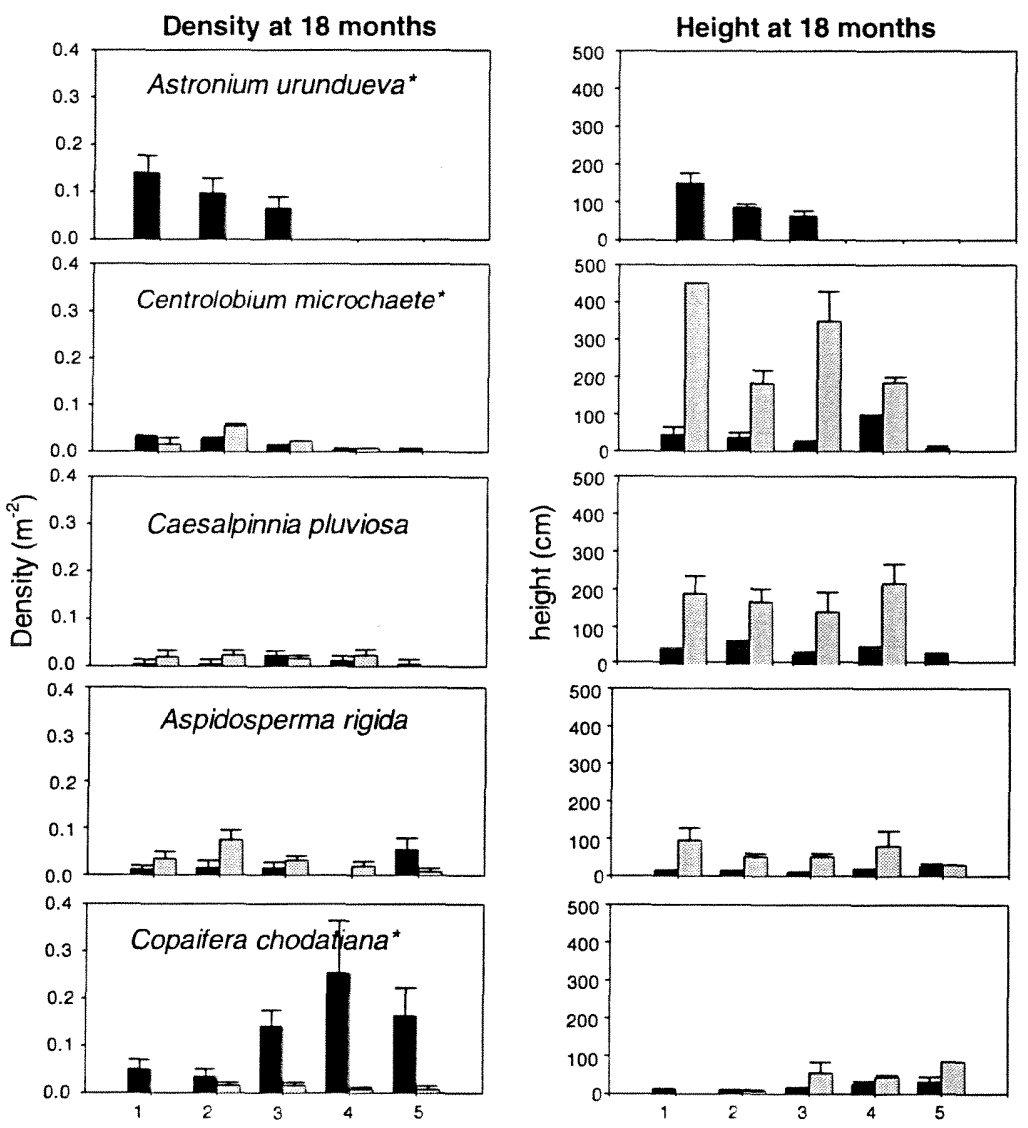

Figure 4. Densities and heights of seedlings (black bars) and sprouts (gray bars) of five commercial species 18 months following burn treatments. Treatment codes along the $x$-axis are: 1 , highintensity burn; 2, low-intensity burn; 3, plant removal; 4, gap control; 5, forest. *indicates species used in seed addition treatment. Bars represent standard errors $(n=16)$.

Centrolobium sprouts were more than 7 times the mean height of Centrolobium seedlings after 18 months $(F=39.2, p=0.003)$. Similarly, RGRs of Centrolobium sprouts were also greater than those of seedlings $(F=13.6$, $p=0.01)$. No differences in height or RGRs were detected among treatments $(F=1.0, p=0.49 ; F=0.1, p=0.97$, respectively).

Copaifera. Copaifera regenerated from both seeds and sprouts, although the overall density of seedlings was more than 10 times higher than sprouts (at 18 months: $X^{2}=35.9, p=0.001$; Figure 4). Copaifera seedlings were most abundant in gap control plots; sprout density did not differ among treatments 
Table 2. Statistical analyses testing for differences in density among gap treatments. Seedling densities could not be normalized, therefore the effect of gap treatments was tested using a Kruskall-Wallis non-parametric test for each month. Seedlings and sprouts were also analyzed separately for these species (if applicable)

\begin{tabular}{|c|c|c|c|c|c|c|c|c|c|c|c|c|c|c|c|c|c|c|}
\hline \multirow[t]{3}{*}{ Mo } & \multirow{2}{*}{\multicolumn{2}{|c|}{$\frac{\text { Astronium }}{\text { scedlings only }}$}} & \multicolumn{4}{|c|}{ Aspidosperma } & \multicolumn{4}{|c|}{ Caesalpinia } & \multicolumn{4}{|c|}{ Centrolobium } & \multicolumn{4}{|c|}{ Copaifera } \\
\hline & & & \multicolumn{2}{|c|}{ seedlings } & \multicolumn{2}{|c|}{ sprouts } & \multicolumn{2}{|c|}{ seedlings } & \multicolumn{2}{|c|}{ sprouts } & \multicolumn{2}{|c|}{ seedlings } & \multicolumn{2}{|c|}{ root suckers } & \multicolumn{2}{|c|}{ seedlings } & \multicolumn{2}{|c|}{ sprouts } \\
\hline & $X^{2}$ & $p$ & $X^{2}$ & $p$ & $X^{2}$ & $p$ & $X^{2}$ & $p$ & $X^{2}$ & $p$ & $X^{2}$ & $p$ & $X^{2}$ & $p$ & $X^{2}$ & $p$ & $X^{2}$ & $p$ \\
\hline 3 & 25.1 & $<0.001$ & 9.9 & 0.04 & 7.7 & 0.10 & 21.2 & 0 & 8.6 & 0.07 & 4.0 & 0.41 & 11.1 & 0.03 & 17.5 & 0.002 & 6.2 & 0.18 \\
\hline 6 & 34.7 & $<0.001$ & 9.9 & 0.04 & 6.7 & 0.16 & 14.6 & 0.006 & 8.6 & 0.07 & 16.2 & 0.003 & 11.2 & 0.02 & 12.8 & 0.01 & 6.2 & 0.18 \\
\hline 9 & 37.6 & $<0.001$ & 4.0 & 0.40 & 12.1 & 0.02 & 11.6 & 0.021 & 6.8 & 0.15 & 11.8 & 0.02 & 23.2 & $<0.001$ & 12.3 & 0.02 & 5.2 & 0.26 \\
\hline 12 & 37.0 & $<0.001$ & 5.5 & 0.24 & 12.0 & 0.02 & 11.6 & 0.021 & 5.6 & 0.23 & 5.6 & 0.24 & 18.5 & 0.001 & 10.4 & 0.03 & 6.1 & 0.19 \\
\hline 18 & 37.5 & $<0.001$ & 7.5 & 0.11 & 12.1 & 0.02 & 4.3 & 0.37 & 5.6 & 0.23 & 2.0 & 0.73 & 21.6 & $<0.001$ & 11.5 & 0.02 & 6.1 & 0.20 \\
\hline
\end{tabular}


(Table 2). Sprouts of Copaifera were taller than seedlings $(F=8.4, p=0.01)$, although their RGRs did not differ $(F=1.8, p=0.20)$. Height and RGRs did not differ among treatments $(F=0.3, p=0.47 ; F=0.3, p=0.84$, respectively).

Caesalpinia pluviosa (unseeded species). Seedlings and sprouts of Caesalpinia occurred with roughly equal frequency (Figure 4). Caesalpinia seedlings were most abundant in forest plots; there was no difference in sprout density among treatments (Table 2). Caesalpinia sprouts were taller than seedlings $(F=9.3$, $p=0.01)$, although RGRs did not differ $(F=0.2, p=0.66)$. Height and RGRs did not differ among treatments $(F=0.1, p=0.95 ; F=0.6$, $p=0.63$, respectively) .

Aspidosperma rigidum (unseeded species). Aspidosperma sprouts were more abundant than seedlings (at 18 months: $X^{2}=10.2, p=0.001$; Figure 4). Differences in seedling density among treatments were only found at 3 and 6 months; at these sampling periods, seedlings were most abundant in the forest understory (Table 2). Sprout density was most abundant in the lowintensity burn treatment after 9,12 and 18 months. Aspidosperma sprouts were taller than seedlings $(F=14.8, p=0.003)$. RGRs among sprouts and seedlings did not differ $(F=0.01, p=0.84)$. There was no pattern in height or RGRs among treatments $(F=3.4, p=0.07 ; F=1.3, p=0.32)$.

\section{Discussion}

\section{Effects of seeding treatment on tree seedling densities}

Higher seedling densities of Centrolobium and Copaifera in seed addition treatments may indicate that seeds are limiting for these two species, either because seed production was low or because seeds failed to reach sites suitable for their germination and establishment (i.e., dispersal limitation; Dalling et al. 1998). Both Copaifera and Centrolobium produced abundant seed in 1997 (Fredericksen et al. 2000), so it is unlikely that seed production was limiting during the year of this study. However, both species show characteristics of dispersal limitation, due to either their dispersal mode and/or the distribution of mature trees. For example, Copaifera seeds mostly fall beneath the parent tree, although some may be carried short distances by ants or small mammals (Fredericksen and Justiniano 1998). Only 4 of 16 gaps had mature Copaifera within $15 \mathrm{~m}$ of the gap edge, so it is likely that naturally dispersed seeds were scarce in the remaining 12 gaps. Centrolobium produces large samaras, fruits that can easily reach gap centers aided by the strong winds of the dry season. However, only 9 of the 16 gaps had mature Centrolobium trees within $15 \mathrm{~m}$ of the gap edge, so it is likely seeds of this species were scarce in the remaining 7 gaps. The timing of seed dispersal relative to burns also may have contributed to the significant effect of the seed addition treatment for both Copaifera and Centrolobium. Seed fall of both Copaifera and Centrolobium occurred before 
controlled burns, therefore seed addition may have been a significant source of seed in burned plots. Seed bank studies indicated that naturally dispersed seeds present in plots before burns were likely damaged or killed (Kennard et al. 2002).

Astronium seedling densities were not increased by seed addition; apparently, seeds were not limiting for this particular species during this study. Rather, seedling densities of Astronium among treatments suggest that seedling recruitment was limited more by the availability of sites suitable for germination and establishment (establishment limitation; Dalling et al. 1998) than by seed production or dispersal. Seedling densities of Astronium were highest in the intensely burned treatments and absent from forest and control plots. This suggests seedling establishment of Astronium is dependent on one or more of the effects caused by intense disturbances, such as canopy opening, vegetation removal, soil exposure, and/or increased soil temperature. It is likely that Astronium seedling establishment was most enhanced by vegetation removal, as seedlings did establish in plant removal treatment plots. Studies have indicated that cover by low vegetation potentially has a more negative impact on newly emerging seedlings than cover higher in the canopy (Marquis et al. 1986). Changes to seed bed conditions caused by controlled burns may also favor seedling establishment of Astronium, as seedling densities were greatest in the burned treatments.

In contrast to the species just discussed, Anadenanthera recruitment did not appear to be limited by seed production, seed dispersal, or suitable germination and establishment sites. Seed production of Anadenanthera was abundant in 1997, and, although Anadenanthera seeds are primarily gravity dispersed (Justiniano and Fredericksen 1998), all 16 gaps had at least one mature Anadenanthera within $15 \mathrm{~m}$ and seeds were dispersed into most gaps (Kennard et al. 2002). Also, seedling establishment does not appear to be controlled by microsite availability as Anadenanthera seedlings were present in all treatments. Although Anadenanthera seedling recruitment was abundant during the year of this study, it may be limited by seed production in other years. For example, seed production of Anadenanthera was extremely low during the second year of this study, and not a single newly germinated seedling was located in treatment plots.

\section{Gap treatment effects on density and survival}

Patterns of commercial tree regeneration among treatments and over the 18 month sampling period varied considerably among species, but three general trends were apparent: species that regenerated primarily from seed (Anadenanthera and Astronium), species that regenerated from both seeds and seedling sprouts (Caesalpinia, Copaifera, Aspidosperma), and species that regenerated mostly by root sprouting or suckering (Centrolobium). Gap treatment effects on densities and survival are discussed for each of these groups. 
Species regenerating as seedlings only. Both Anadenanthera and Astronium had abundant seed fall in 1997 , and moderate to high germination rates, creating a large seedling cohort soon after treatments. However, patterns of seedling density and survival among treatments differed for these two species. As discussed earlier, patterns of Astronium establishment suggest that its seedlings are unable to establish or survive under shade; no seedlings were recorded in either forest understorey or gap control plots. In contrast, Anadenanthera seedlings were initially most abundant in forest plots. This density pattern is likely a combination of higher seed fall into forests than gaps (Kennard et al. 2002) and, unlike Astronium, the ability of Anadenanthera seedlings to persist in shade, at least for short periods. However, due to high mortality of Anadenanthera seedlings in forest understories, patterns of seedling distribution among treatments may resemble those of Astronium after several years. Therefore, the burn and plant removal treatments appeared to enhance establishment of Astronium seedlings and survival of Anadenanthera seedlings. In other neotropical forests, the abundance of species colonizing from seed have been shown to increase in canopy gaps that have been further disturbed by either logging (Mexico: Dickinson 1998) or fire (Amazonian Brazil: Holdsworth and Uhl 1997). The lack of sprout regeneration of both Astronium and Anadenanthera was likely due to the lack of seedlings or saplings in the forest stand before treatments were applied.

Species regenerating as both seedlings and sprouts. Seedling banks of Copaifera, Caesalpinia, and Aspidosperma were present in forest understories before treatments. Patterns of regeneration immediately following treatments likely reflect what happened to this seedling bank during treatments: sprouts were most abundant in treatments where this seedling bank was damaged, and seedlings were most abundant where a portion of this seedling bank survived undamaged. Increases in seedling density from newly established seedlings were not apparent for 6-12 months following treatments for these species; seed germination of Copaifera and Aspidosperma is slow, and seedfall of Caesalpinia was low the first year. More specific trends would be possible to discern if individuals of these advanced regenerating species had been tagged prior to treatment.

Patterns of regeneration among these species stresses the important role advance regeneration plays in determining the success of shade-tolerant species following disturbances. Where advance regeneration is abundant, less intense disturbances such as canopy gap formation will favor these species. However, more intense disturbances, such as severe fire, may kill advance regeneration thus favoring species that colonize from seed. Similarly, in a study conducted in Mexico, Dickinson (1998) reported that shade-tolerant species were most abundant in forest understories and natural canopy gaps, but in logging gaps, skidder damage reduced the abundance of these species.

Species regenerating as root sprouts. Natural regeneration of Centrolobium consisted of root suckers from the root systems of mature trees. Despite seed addition, Centrolobium seedling densities were very low, likely due to low seed 
viability ( $4 \%$ in seed germination trials). In fact, we found no seedlings arising from naturally dispersed seed in experimental plots despite nearby seed sources in 9 of 16 gaps. Also, no seedling sprouts were found in plots, likely due to the lack of seedlings in forest understories before treatments.

Root sprouting of Centrolobium was most abundant in the plant removal and burn treatments. This pattern agrees with studies of temperate species which indicated that root sprouting develops after roots are injured or exposed to air or elevated temperatures; root damage leads to the formation of callus, tissue from which adventitious buds and sprouts arise (e.g., Fagus grandifolia; Jones and Raynal 1988). Similarly, Dickinson (1998) found that traversal by skidders during logging operations promoted subsequent root sprouting by several dry forest tree species in Mexico. Root-sprouting may also be promoted by the loss of apical dominance (e.g., for Populus tremuloides; Schier 1975). This mechanism would account for high densities of root sprouts in gap control plots where stumps of harvested Centrolobium were located. Similarly, root sprouts of Platymiscium uleii were found only in the plant removal and burn treatments, and may have the same regeneration strategy as Centrolobium.

\section{Gap treatment effects on heights and RGRs}

Treatment effects on heights and RGRs also revealed a general pattern according to species' regeneration strategy. In general, species that regenerated primarily by seed (Anadenanthera, Astronium) revealed patterns of treatment effects on height, while species that regenerated by sprouting (Centrolobium) or a combination (Caesalpinia, Copaifera, Aspidosperma) did not show significant treatment effects.

Species regenerating as seedlings only. Seedlings of both Anadenanthera and Astronium were tallest in high-intensity burn plots and average height decreased with decreasing treatment intensity. The high growth rates of these seedlings establishing after high-intensity burns may be due to reduced competition or increased soil nutrients. High intensity burns had the slowest recovery of vegetation among all gap treatments as well as higher concentrations of inorganic nitrogen, phosphorous, and cations $(\mathrm{Ca}, \mathrm{Mg}$, and $\mathrm{K}$; Kennard and Gholz 2001). It is not clear from this study which factor had more of an effect on seedling growth, increased light availability or increased soil nutrients. Seedlings of Anadenanthera were taller in gap centers than gap edges, which suggests that even slight increases in light availability can enhance seedling growth. However, the greater height of Anadenanthera seedlings in low-intensity burn treatments suggests that below-ground effects may also significantly increase seedling growth. Recovery of vegetation after lowintensity burn and plant removal treatments was not significantly different, but soils sampled after low-intensity burns had significantly higher concentrations of soil nutrients. Similarly, other studies conducted in dry forests suggest that reduced below-ground competition appears to benefit seedling growth (Costa 
Rica: Gerhardt and Fredrickson 1995; Gerhardt 1996; Mexico: Dickinson 1998).

Species regenerating as both seedlings and sprouts. Among most of the species regenerating as both seedlings and sprouts, there was no effect of treatments on height or RGR. This pattern may be because any possible treatment effects were obscured by the tremendous height differences between seedlings and sprouts. Sprouts were taller than conspecific seedlings therefore the height of an individual was more dependent on whether it was a seedling or sprout rather than treatment.

This lack of significance may also have reflected a real lack of difference in seedling or sprout growth among treatments. Growth of sprouts may have been less influenced by treatments because they depend on stored carbohydrate reserves in roots and therefore are less affected by above- and below-ground competition during early developmental stages. Seedling growth of these particular species may have been less affected by treatments than seedlings of Anadenanthera and Astronium because they are more shade-tolerant; shadetolerant species grow more slowly than shade-intolerant species, even in high light (e.g., Denslow 1987; Denslow et al. 1990).

Also, differences in below-ground effects among treatments may have been less important for shade-tolerant species due to their slower growth rates. The relative importance of below-ground effects has been shown to differ among shade-tolerant and intolerant species. For example, Dickinson (1998) reported that reduced root competition did not increase seedling height of a shadetolerant species, as it did for Swietenia. Also, Denslow et al. (1998) reported that whereas light-demanding species responded better to increased soil nutrients in high light, shade-tolerant species showed no response.

Species regenerating as root sprouts. Centrolobium root sprouts were more than 7 times taller than conspecific seedlings, a greater height difference than observed in all other species regenerating from both seeds and sprouts. Centrolobium sprouts may grow more rapidly than sprouts of other species because they sprout from the root systems of mature trees and therefore have larger carbohydrate reserves to utilize than sprouts of other species, which mostly originated from juveniles.

\section{Conclusions}

The wide variation in species' responses to gap treatments found in this study not only reinforces the concept that species are distributed along of a continuum of shade-tolerance levels, but that other aspects of species' biology, such as seed dispersal type or sprouting behavior, further differentiate regeneration strategies. This wide variation in regeneration strategies precludes blanket silvicultural treatments. Other researchers have recognized this pattern and have suggested mixed management schemes for these dry forests, with an evenaged management system for more shade-intolerant species involving the 
creation of large multiple-treefall gaps, and an uneven-aged management system for more shade-tolerant species involving the creation of smaller singletreefall gaps (Pinard et al. 1999). However, the results of this study suggest that even large, multiple-treefall gaps may not provide suitable habitat for more shade-intolerant species. Poor recruitment of Anadenanthera and Astronium seedlings in gap control plots suggest that advance regeneration, logging debris, and deep litter in treefall gaps limit suitable sites for the establishment and survival of these species. Therefore, selective logging without additional silvicultural treatments, such as slash removal or prescribed burning, are not sufficient to improve regeneration of these shade-intolerant species.

By decreasing competing vegetation and increasing soil nutrients, the high intensity burn treatment improved growth and survival of shade-intolerant commercial tree species. However, because high-intensity burns negatively affect species that depend on seed or seedling banks for regeneration and may have long term effects on soil physical properties (Kennard and Gholz 2001), they are not advisable from an ecological standpoint. Moreover, high-intensity burns are not feasible on a management scale due to the high labor costs involved (Kennard et al. 2002) and the high risk of fire escapes. The results of this study suggest that low-intensity burns are not likely to benefit commercial tree regeneration, however burns of medium-intensity may be sufficient. More research is needed to identify what range of burning conditions is suitable for managing shade-intolerant species and what types of prescribed burns would be economically and logistically feasible in these dry forests.

This study also supports conclusions drawn by other researchers that advanced regeneration is an important source of post-disturbance regeneration among shade-tolerant species. The importance of advanced regeneration creates a conflict between promoting regeneration of shade-intolerant species with intense silvicultural treatments while trying to maintain regeneration of shadetolerant species. In this study, most advanced regeneration was killed by highintensity burns. Therefore, where advanced regeneration of shade-tolerant species is abundant, less intense treatments that would release seedlings/saplings of competition, such as weeding and/or thinning, would be more suitable than prescribed burning.

\section{Acknowledgments}

This work was funded by BOLFOR (Proyecto de Manejo Forestal Sostenible), Santa Cruz, Bolivia. Field work was conducted in the Las Trancas communityowned forest, Lomerio. E. Stone, K. Kitajima, G. Tanner, T. Fredericksen, and J. McDaniel provided constructive comments on an earlier draft. We thank J. McDaniel, L. MacDonald, J. Chuviru, T. Fredericksen, N. Fredericksen, J. Justiniano, J. Pesoa, J. Faldin, and numerous additional Chiquitano community members for assisting with fieldwork. 


\section{References}

Augspurger C.K. 1984. Seedling survival of tropical tree species: interactions of dispersal distance, light gaps, and pathogens. Ecology 65: 1705-1712.

Brokaw N.V.L. 1985. Gap-phase regeneration in a tropical forest. Ecology 66: 682-687.

Condit R., Hubbell S.P. and Foster R.B. 1996. Assessing the response of plant functional types to climatic change in tropical forests. J. Veg. Sci. 7: 405-416.

Dalling J.W., Hubbell S.P. and Silvera K. 1998. Seed dispersal, seedling establishment, and gap partitioning among tropical pioneer trees. J. Ecol. 86: 674-689.

Denslow J.S. 1987. Tropical rainforest gaps and tree species diversity. Ann. Rev. Ecol. Syst. 18: $431-451$.

Denslow J.S., Schultz J.C., Vitousek P.M and Strain B.R. 1990. Growth responses of tropical shrubs to treefall gap environments. Ecology 7: 165-179.

Denslow J.S., Ellison A.M. and Sandford R.E. 1998. Treefall gap size effects on above- and belowground processes in a tropical wet forest. J. Ecol. 86: 597-609.

Dickinson M.B. 1998. Tree regeneration in natural and logging canopy gaps in a semideciduous dry tropical forest. Ph.D. Dissertation, Florida State University, Tallahasee, FL.

Dinerstein E.D., Olson M., Graham D.J., Webster A.L., Rim A.A., Bookbinder N.P. and Ledic G. 1995. A conservation assessment of the terrestrial eco-regions of Latin America and the Caribbean. WWF-The World Bank, Washington DC, US.

Fredericksen T.S. and Justiniano J. 1998. Ecologia de Especies Menos Conocidas: Sirari. Proyecto BOLFOR, Santa Cruz, Bolivia.

Fredericksen T.S., Justiniano J.M., Mostacedo B., Kennard D. and MacDonald L. 2000. Comparative regeneration ecology of three leguminous timber species in a Bolivian tropical dry forest. New Forests 12: 15-34.

Garwood N.C. 1983. Seed germination in a seasonal tropical forest in Panama: a community study. Ecol. Monogr. 53: 159-181.

Gentry A. 1993. Dry forest vegetation and phytogeography in the Tucavaca Valley. In: Parker T.A. III, Gentry A.H, Foster R.B., Emmons L.H. and Remsen J.V. Jr. (eds), The Lowland Dry Forests of Santa Cruz, Bolivia: A Global Conservation Priority. Conservation International, RAP Working Papers, No. 4. pp. 40-53.

Geobold M. 1981. Mapa geologico del area de Concepcion (Cuad SE 20-3, con parte de SE 20-2) Proyecto Precambrico, Servicio Geologico de Bolivia. Regional Santa Cruz y Institute of Geological Sciences, National Environment Research Council, UK.

Gerhardt K. and Fredrikson D. 1995. Biomass allocation by broad-leaf mahogany seedlings, Swietenia macrophylla (King), in abandoned pasture and secondary dry forest in Guanacaste, Costa Rica. Biotropica. 27: 174-182.

Gerhardt K. 1996. Germination and development of sown mahogany (Swietenia macrophylla King) in secondary tropical dry forest habitats in Costa Rica. J. Trop. Ecol. 12: 275-289.

Hartshorn G.S. 1989. Application of gap theory to tropical forest management: natural regeneration on strip clear-cuts in the Peruvian Amazon. Ecology 70: 567-569.

Holdridge L.R. 1967. Life Zone Ecology. Tropical Science Center, San Jose, Costa Rica.

Holdsworth A.R. and Uhl C. 1997. Fire in Amazonian selectively logged rain forest and the potential for fire reduction. Ecol. Appl. 7: 713-725.

Iporre J.B. 1996. Estudio de Suelos en Los Areas de Accion Forestal Zona Lomerio. Technical Document, BOLFOR, Santa Cruz, Bolivia

Jones R.H. and Raynal D.J. 1988. Root sprouting in American beech (Fagus grandifolia): effects of root injury, root exposure and season. Forest Ecol. Manage. 25: 79-90.

Justiniano J. and Fredericksen T.S. 1998. Ecologia de Especies Menos Conocidas: Curupau. Proyecto BOLFOR, Santa Cruz, Bolivia.

Kennard D.K. and Gholz H.L. 2001. Effects of high and low intensity fire on soil properties and plant growth in a Bolivian dry forest. Plant Soil 234: 119-129. 
Kennard D.K., Gould K.A., Putz F.E., Fredericksen T.S. and Morales F. 2002. Effects of disturbance intensity on regeneration mechanisms in a tropical dry forest. Forest Ecol. Manage. 162: 197-208.

Killeen T., Jardim A., Manami F., Saravia P. and Rojas N. 1998. Diversity, composition, and structure of a tropical deciduous forest in the Chiquitania region of Santa Cruz, Bolivia. J. Trop. Ecol. 14: 803-827.

Killeen T., Louman B.T. and Grimwood T. 1990. La ecologia paisajistica de la region de Concepcion y Lomerio en la Provincia de Nuflo de Chavez, Santa Cruz, Bolivia. Ecologia en Bolivia 16: $1-45$.

MacDonald E., Wright K., Latchford R., Lerias P. and Leach R. 1998. University of Aberdeen Expedition Report. Aberdeen, Scotland

Marquis R.J., Young H.J. and Braker H.E. 1986. The influence of understory vegetation cover on germination and seedling establishment in a tropical lowland wet forest. Biotropica 18: 273-278.

Mostacedo B. and Fredericksen T.S. 1999. Regeneration status of important forest tree species in Bolivia: Assesment and recommendations. Forest Ecol. Manage. 124: 263-273.

Nittler J.B. and Nash D.W. 1999. The certification model for forestry in Bolivia. J. Forest. 97: 3236.

Pinard M.A., Putz F.E., Rumiz D., Guzman R. and Jardim A. 1999. Ecological characterization of tree species for guiding forest management decisions in seasonally dry forests in Lomerio, Bolivia. Forest Ecol. Manage. 113: 201-213.

Schier G.A. 1975. Promotion of root sucker development on Populus tremuloides root cuttings by an antiauxin. Can. J. Forest Res. 5: 338-340.

SPSS 1998. SPSS for Windows, Version 9.0.0. SPSS, Inc.

Stanley S.A. 1995. Report on the Methodology Utilized in the Study: Use of Prescribed Burning to Foment the Regeneration of Commercial Tree Species in Lomerio, Santa Cruz, Bolivia. BOLFOR Technical Document, Santa Cruz, Bolivia.

Whitmore T.C. 1989. Canopy gaps and the two major groups of forest trees. Ecology 70: 536-538. 